\title{
PENGEMBANGAN MULTIMEDIA PEMBELAJARAN BERBASIS INKUIRI TERHADAP HASIL BELAJAR IPA
}

\author{
I Gede Edy Indrawan \\ Program studi Teknologi Pendidikan, Universitas Pendidikan Ganesha \\ igede.edyindrawan@undiksha.ac.id \\ Nyoman Jampel \\ Program studi Teknologi Pendidikan, Universitas Pendidikan Ganesha \\ jampel@undiksha.ac.id \\ Luh Putu Putrini Mahadewi \\ Program studi Teknologi Pendidikan, Universitas Pendidikan Ganesha \\ lpp-mahadewi@undiksha.ac.id
}

\begin{abstract}
Abstrak
Permasalahan yang dihadapi di SMP Negeri 2 Gerokgak adalah terbatasnya media yang mampu memvisualisasikan materi pelajaran.sehingga dilakukan penelitian yang bertujuan (1) untuk mendeskripsikan rancang bangun multimedia pembelajaran pada mata pelajaran IPA, (2) untuk mengetahui kualitas multimedia pembelajaran menurut review ahli, dan uji coba yang dilakukan siswa, serta (3) untuk mengetahui efektivitas multimedia pembelajaran mata pelajaran IPA. Model pengembangan yang digunakan adalah model Luther. Validasi multimedia dilakukan oleh ahli isi mata pelajaran, ahli desain pembelajaran, ahli media pembelajaran, uji coba perorangan, uji coba kelompok kecil, dan uji coba lapangan. Efektivitas multimedia dilakukan oleh 29 siswa menggunakan desain penelitian pre-test dan post-test. Data dikumpulkan dengan metode wawancara, pencatatan dokumen, kuesioner dan tes objektif. Analisis data menggunakan analisis deskriptif kualitatif, kuantitatif dan statistik inferensial/induktif uji-t.Hasil penelitian ini adalah (1) rancang bangun pengembangan multimedia interaktif mulai dari langkah analisis, desain, pengembangan, implementasi dan evaluasi; (2) Validitas hasil pengembangan media menurut review ahli dan siswa yaitu: a) ahli isi pembelajaran 92,5\% berada pada kategori sangat baik; b) ahli desain pembelajaran $92,22 \%$ berada pada kategori sangat baik; c) ahli media pembelajaran 84,7\% berada pada kategori baik; d) uji coba perorangan $90 \%$ berada pada kategori sangat baik; e) uji coba kelompok kecil 89\% berada pada kategori sangat baik; f) dan uji coba lapangan 87,7\% yang berada pada kategori baik; (3) berdasarkan uji hipotesis ditunjukkan bahwa harga thitung $=14,10>$ ttabel $=2,003$. Dengan demikian multimedia pembelajaran ini efektif untukmeningkatkan hasil belajar IPA di SMP Negeri 2 Gerokgak.
\end{abstract}

Kata Kunci: IPA, multimedia pembelajaran, pengembangan

\begin{abstract}
The problem is faces by SMP Negeri 2 Gerokgak is there no enough media that can visualize the learning material needed. so that a purposeful research is carried out (1) to describe the design of multimedia learning on science subjects, (2) to find out the quality of multimedia learning according to expert review, and trials conducted by students, (3) to find out the effectiveness of multimedia learning in science subjects. The development model used is the Luther model. Multimedia validation is done by subject matter experts, learning design experts, learning media experts, individual trials, small group trials, and field trials. The effectiveness of multimedia is carried out by 29 students using the research design pre-test and post-test. Data was collected by interview method, recording documents, questionnaires and objective tests. Data analysis used descriptive qualitative, quantitative and inferential / inductive statistical t-test. The results of this study are (1) design of interactive multimedia development starting from the steps of analysis, design, development, implementation and evaluation; (2) The validity of the results of the development of media according to the review expert and the students are: (a) $92.5 \%$ learning content experts are in a very good category; (b) 92.22\% learning design experts are in a very good category; (c) learning media experts $84.7 \%$ are in the good category; (d) $90 \%$ individual trials are in a very good category; e) $89 \%$ small group trials included in the excellent category; $(f)$ and $87.7 \%$ field trials were in the good category; (3) based on the hypothesis test indicated that the price of tcount $=14.10>t$ table $=2.003$. Thus this multimedia learning is effective for improving science learning outcomes in SMP Negeri 2 Gerokgak.
\end{abstract}

Keywords : sains, multimedia learning, development 


\section{Pendahuluan}

Perkembangan ilmu pengetahuan dan teknologi memungkinkan semua pihak dapat memperoleh informasi dengan cepat, mudah dan melimpah dari berbagai sumber dan tempat di dunia.Selain perkembangan yang pesat, perubahan ilmu pengetahuan dan teknologi juga terjadi dengan cepat.Oleh karena itu untuk dapat bertahan pada keadaan teknologi yang selalu berubah, maka diperlukan kemampuan yang memadai.Kemampuanini membutuhkan pemikiran yang sistematis, logis dan kritis yang dapat dikembangkan dalam proses pembelajaran yang nantinya dapat meningkatkan mutu pendidikan.

Dalam upaya peningkatan mutu pendidikan di Indonesia, pemerintah telah melakukan berbagai upaya yang mencakup hampir seluruh komponen pendidikan seperti pengadaan buku-buku pelajaran, peningkatan kualitas guru, kurikulum, pembaharuan kurikulum, pengadaan alat peraga dan usaha lainnya yang berkaitan dengan kualitas pendidikan. Berbicara mengenai pendidikan tentu tidak dapat terlepas dari lembaga penyelenggara pendidikan yaitu sekolah.Sekolah sebagai lembaga formal merupakan sarana dalam rangka mencapai tujuan pendidikan.Di sekolah, siswa belajar berbagai macam hal, tidak hanya pengetahuan semata tetapi juga memperoleh keterampilan dan kecakapan. Pembelajaran di Sekolah khususnya di SMP untuk kelas VII dalam penjelasannya guru sebaiknya menjelaskan dalam bentuk kongkrit karena siswa kelas VII masih berada dalam ranag kogntifi kongkrit. Siswa akan lebih cepat belajar dalam bentuk nyata, misalnya seperti praktik langsung sehingga siswa memperoleh dan mendapatkan informasi dengan melakukan observasi dan atau eksperimen untuk mencari jawaban atau memecahkan masalah terhadap pertanyaan atau rumusan masalah dengan menggunakan kemampuan berpikir kritis dan logis.

Berdasarkan hasil wawancara bersama bapak Made astika S.Pd. guru IPA kelas VII di SMP Negeri 2 Gerokgak untuk nilai rata-rata siswa kelas VII pada mata pelajaran Ilmu Pengetahuan Alam (IPA) masih belum maksimal. Hal tersebut terjadi dikarenakan Berdasarkan pengamatan peneliti selama pembelajaran dan kajian pustaka dokumen pembelajaran, 1) guru menerangkan materi hanya di kelas saja dengan menggunakan metode ceramah, padahal materi yang diajarkan tentang tata surya sebaiknya menggunakan alat praga namun setelah di cek alat praga yang tersedia sudah tidak layak lagi, 2) guru sudah terbiasa menggunakan teori belajar behavioristik dimana komunikasi materi hanya dari guru saja hal ini berdampak siswa tidak dapat mengkonstruksikan pikiran untuk mencari tahu sendiri materinya, 3) guru belum menggunakan media pembelajaran yang inovatif, padahal penggunaan media pembelajaran dapat menarik perhatian siswa terhadap materi, 4) berdasarkan kajian pustaka dokumen pembelajaran berupa adminsitrasi guru, RPP yang dibuat guru belum mampu membuat siswa untuk mengkontruksikan pikirannya.

Berdasarkan permasalahan tersebut maka diperlukan solusi yaitu dengan melakukan pengembangan multimedia pembelajaran berbasis inkuri. Penggunaan multimedia pembelajaran dapat menghasilkan media yang lebih inovatif karena bisa dikembangkan lebih menarik perhatian siswa karena disesuaikan dengan karakteristik siswa dalam belajar. Penggunaan pendekatan ingkuiri bertujuan supaya siswa dapat memperoleh dan mendapatkan informasi dengan melakukan observasi dan atau eksperimen untuk mencari jawaban atau memecahkan masalah terhadap pertanyaan atau rumusan masalah dengan menggunakan kemampuan berpikir kritis dan logis. Alsannya pemilihan multimedia pembelajaran ini juga didasari oleh penelitian yang dilakukan oleh Priyanto (2016) bahwa Media pembelajaran ini dapat membantu siswa dalam pemahaman dan menekankan pada pengembangan kemampuan siswa merumuskan masalah atas fenomena yang diamati, mengumpulkan data terkait, menganalisis masalah tersebut, sampai pada menyimpulkan apa yang menjadi temuan.

Pengembangan multimedia pembelajaran ini juga didukung oleh guru mampu mengoperasikan komputer serta fasilitas LCD tersedia di sekolah. Jika siswa ingin membuka untuk mempelajarinya secara mandiri siswa dapat menggunakan fasilitas lab komputer yang ada disekolah.

Multimedia pembelajaran ini bisa diterapkan pada sekolah lain yang sudah menggunakan kurikulum 2013 pada pembelajaran IPA kelas VII. Pengguannya tidak terlalu sulit untuk digunakan siswa yang sudah melek teknologi dan akan diberikan petunjuk penggunaan supaya.

Berdasarkan paparan diatas, adapun beberapa tujuan dari penelitian ini, yakni: (1) Untuk mendeskripsikan rancang bangun multimedia pembelajaran pada mata pelajaran IPA untuk kelas VII semester genap di SMP Negeri 2 Gerokgak tahun pelajaran 2018/2019. (2) Untuk menguji validitas multimedia pembelajaran pada mata pelajaran IPA untuk kelas VII semester genap di SMP Negeri 2 Gerokgak tahun pelajaran 2018/2019 yang di terapkan pada kelompok kecil. (3) Untuk mengetahui efektivitas penggunaan multimedia pembelajaran dalam pembelajaran IPA kelas VII semester genap di SMP Negeri 2 Gerokgaktahun pelajaran 2018/2019.

\section{Metode}

Model yang menjadi acuan dalam pengembangan multimedia pembelajaran pada mata pelajaran IPA, khususnya untuk siswa SMP Negeri 2 Gerokgak adalah model pengembangan Luther. Pemilihan model pengembangan ini didasari atas pertimbangan bahwa model ini dikembangkan secara sistematis. Model ini disusun secara terprogram dengan urutan kegiatan yang sistematis dalam upaya pemecahan masalah belajar yang 
berkaitan dengan pengembangan produk media pembelajaran yang sesuai dengan kebutuhan dan karakteristik siswa. Ada 6 tahap dalam model ini, yaitu: (1) Konsep (Concept), (2) Perancangan (Design), (3) Pengumpulan bahan (Material Collecting), (4) Pembuatan (Assembly), (5) Uji coba (Testing), (6) Distribusi (Distribution).

Subjek validasi produk pada penelitian ini dilakukan oleh satu orang ahli isi mata pelajaran yang merupakan seorang guru yang mengajar mata pelajaran IPA kelas VII SMP Negeri 2 Gerokgak, satu orang ahli desain pembelajaran, dan satu orang ahli media pembelajaran. Subjek uji cobaperorangan terdiri atas 3 (tiga)orang siswa kelas VII SMP Negeri 2 Gerokgak. Siswa-siswa tersebut terdiri dari satu orang siswa dengan hasil belajar IPA tinggi, satu orang siswa dengan hasil belajar IPA sedang, dan satu orang siswa dengan hasil belajar

IPA rendah. Subjek uji coba kelompok kecil terdiri atas 5 (lima) orang siswa kelas VII SMP Negeri 2 Gerokgak. Kelima orang siswa tersebut, terdapat dua orang siswa dengan hasil belajar IPA tinggi, dua orang siswa dengan hasil belajar IPA sedang, dan satu orang siswa dengan hasil belajar IPA rendah. Subjek Uji coba lapangan menggunakan siswa kelas VIISMP Negeri 2 Gerokgakyang berjumlah 29 orang.

Untuk menguji kelayakan intrumen dalam bentuk tes dilakukan uji validitas tes yang berdasarkan pertimbangan ahli isi (uji judges) dari seorang guru pada bidang studi yang sama yang memiliki kualifikasi dan pengalaman kerja yang cukup. Setelah dilakukan uji judges maka tes diuji keterbacaannya ditinjau dari pemakai (siswa) melalui uji kelompok kecil dan kelas yang sesungguhnya. Berdasarkan hasil tes uji coba, diperoleh hasil validitas butir soal yang valid sebanyak 30 soal. Selanjutnya dilakukan uji reliabilitas tes untuk mengetahui tingkat kepercayan dari tes tersebut. Berdasarkan hasil perhitungan yang dilakukan, maka diketahui bahwa instrumen memiliki reliabilitas r1.1 sebesar 0.88382. Hasil tersebut jika dikonversikan kedalam derajat reliabilitas tes yang dikemukakan oleh Guilford termasuk kedalam kriteria sangat tinggi.Selain itu juga dicari taraf kesukaran tes keseluruhannya memiliki taraf sedang.

Dalam penelitian pengembangan ini digunakan tiga teknik analisis data, yaitu teknik analisis deskriptif kuantitatif,teknik analisis deskriptif kualitatif dan Metode Analisis Statistik Inferensial/ Induktif.

(1) Analisis deskriptif kuantitatif digunakan untuk mengolah data yang diperoleh melalui angket dalam bentuk skor.

Untuk dapat memberikan makna dan pengambilan keputusan digunakan ketetapan konversi tingkat pencapaian dengan skala lima yaitu sebagai berikut.

Tabel 1. Konversi Tingkat Pencapaian dengan Skala 5

\begin{tabular}{lll}
\hline $\begin{array}{l}\text { Tingkat } \\
\text { Pencapaian }\end{array}$ & Kualifikasi & Keterangan \\
\hline $90 \%-100 \%$ & Sangat baik & Tidak perlu direvisi \\
$75 \%-89 \%$ & Baik & Direvisi Seperlunya \\
$65 \%-74 \%$ & Cukup & Cukup Banyak Direvisi \\
$55 \%-64 \%$ & Kurang & Banyak Direvisi \\
$0-54 \%$ & Sangat Kurang & Direvisi Total \\
\hline
\end{tabular}

Sumber : Tegeh, dkk $(2014: 83)$

(2) Analisis deskriptif kuantitaif. Data dalam penelitian kualitatif bersifat deskriptif bukan angka. Data dapat berupa gejala-gejala, kejadian dan peristiwa yang kemudian dianalisis dalam bentuk kategori-kategori.

(3) Analisis Statistik inferensial digunakan untuk mengetahui tingkat keefektifan produk terhadap hasil belajar IPA pada siswa kelas VII SMP Negeri 2 Gerokgak, sebelum dan sesudah menggunakan produk pengembangan multimedia pembelajaran dalam mata pelajaran IPA. Data uji coba kelompok sasaran dikumpulkan dengan menggunakan pre-test dan post-testterhadap materi pokok yang diuji cobakan.

Hasil pre-test dan post-test kemudian dianalisis menggunakan uji t untuk mengetahui perbedaan antara hasil pre-test dan post-test. Pengujian hipotesis digunakan untuk uji t berkorelasi dengan bantuan program komputer SPSS dan/atau penghitungan hasil dengan penghitungan manual. Sebelum melakukan uji hipotesis (uji $\mathrm{t}$ berkorelasi) dilakukan uji prasyarat (normalitas dan homogenitas). Rumus untuk menghitung uji prasyarat dan uji hipotesis (uji t berkorelasi) adalah sebagai berikut.

a) Uji normalitas dilakukan untuk mengetahui apakah sebaran skor pada setiap variable berdistribusi normal atau tidak, untuk itu dapat digunakan rumus Chi-Kuadrat.

b) Uji homogenitas ini dilakukan untuk mencari tingkat kehomogenan secara dua pihak yang diambil darikelompok-kelompok terpisah dari satu populasi, yaitu kelompok pre-test dan post-test

c) Uji Hipotesis (Uji t berkolerasi)

Teknik analisis yang digunakan untuk pengujian hipotesis adalah dengan teknik analisis uji t berkorelasi atau dependen. Dasar penggunaan teknik uji t berkorelasi ini adalah menggunakan dua perlakuan yang berbeda 
terhadap satu sampel. Pada penelitian ini akan menguji perbedaan hasil belajar IPA sebelum dan sesudah menggunakan produk multimedia pembelajaran terhadap satu kelompok.

Hasil uji coba dibandingkan $\mathrm{t}_{\text {tabel }}$ dengan taraf signifikan 0,05 (5\%) untuk mengetahui apakah ada perbedaan antara sebelum dan sesudah menggunakan produk multimedia pembelajaran.

\section{Hasil dan Pembahasan}

Produk yang dikembangkan adalah multimedia pembelajaran berbasis inkuiri. Pengembangan Multimedia Pembelajaran berbasis inkuiri ini telah dikembangkan melalui beberapa tahapan sesuai dengan model pengembangan model Luther. Uttami \& Datta (2017) menyebutkan model Luther ini memiliki langkahlangkah pengembangannya sistematis, disajikan secara ringkas, dan dan setiap langkah dipaparkan secara jelas. Tahapan-tahapan dari model Luther yaitu: (1) Konsep (Concept) adalah tahap untuk menentukan tujuan dan siapa pengguna program (identifikasi audiens). Karakteristik pengguna termasuk kemampuan pengguna. Berdasarkan analisis siswa yang telah dilakukan siswa SMP Negeri 2 Gerokgak lebih tertarik belajar menggunakan multimedia pembelajaran daripada menggunakan metode ceramah. Selain itu, tahap ini juga menentukan jenis aplikasi (presentasi, interaktif, dan lain-lain). Jenis multimedia yang dikembangkan dalam penelitian ini adalah multimedia presentasi. (2) Design (perancangan) adalah tahap pembuatan spesifikasi mengenai arsitektur program, gaya, tampilan, dan kebutuhan material/bahan untuk program. Untuk menggambarkan aliran dari satu scene ke scene lain perlu dibuat bagian alir (flowchart). Selanjutnya, berdasarkan flowchart disusun storyboard untuk menggambarkan deskripsi tiap scene, dengan mencantumkan semua objek multimedia dan tautan ke scene lain. Pembuatan storyboard menggunakan cara pembuatan storyboard film/animasi. (3) Pengumpulan bahan (Collecting material) ini berupa pengumpulan bahan atau materi pelajaran yang diperlukan untuk pembuatan produk, seperti materi pokok (substansi mata pelajaran IPA), aspek pendukung seperti gambar, video, audio, dan clip-art image. Pengumpulan materi pokok dilakukan dengan menggunakan buku mata pelajaran IPA yang digunakan di SMP Negeri 2 Gerokgak, sedangkan pengumpulan gambar, video, dan audio diperoleh melalui pembuatan sendiri, arsip pribadi, ataupun men-download melalui internet serta pengambilan langsung di lapangan. (4) Pembuatan (Assembly) merupakan tahap untuk menyusun materi pelajaran IPA yang telah disiapkan dan dimasukkan pada setiap halaman/frame dengan menggunakan software yang sudah ditentukan. Pada tahap ini dilakukan perakitan media/penggabungan seluruh bahan seperi materi pelajaran, gambar, animasi, teks, audio, dengan bantuan software Macromedia Flash 8, Adobe Photoshop CS5, Sony Vegas Pro. Penggabungan ini dimaksudkan agar komponen-komponen multimedia menjadi satu media utuh. (5) Uji coba (Testing) Uji coba media merupakan hal yang terpenting dalam pengembangan media pembelajaran ini. Tahap Testing (pengujian) dilakukan setelah menyelesaikan tahap assembly dengan menjalankan aplikasi/program dan melihatnya apakah ada kesalahan atau tidak. Tahapan uji selanjutnya dalam pengembangan media ini, meliputi uji coba ahli isi mata pelajaran, uji coba ahli desain pembelajaran, uji coba ahli media pembelajaran, uji coba perorangan dengan, uji kelompok kecil, dan uji coba lapangan. (6) Distribusi (Distribution) adalah tahap penyebarluasan produk hasil pengembangan. Pada tahap ini dilakukan kegiatan berupa distribusi produk CD multimedia presentasi kepada guru IPA kelas VII di SMP Negeri 2 Gerokgak.

Validitas hasil pengembangan multimedia pembelajaran iniakan disajikan mulai dari uji ahli isi mata pelajaran, uji ahli desain pembelajaran, uji ahli media pembelajaran, uji coba perorangan, uji coba kelompok kecil dan uji coba lapangan.Uji Ahli Isi Mata Pelajaran, berdasarkan hasil penilaian dari ahli isi melalui instrumen berupa angket, yaitu guru kelas VII dalam mata pelajaran IPA di SMP Negeri 2 Gerokgak atas nama Made Astika, S.Pd terungkap bahwa penilaian guru dalam mata pelajaran IPA terhadap komponen komponen Multimedia Pembelajaran berbasis inkuiri tersebar pada skor 4 (baik) dan 5 (sangat baik). Kualitas media ditinjau dari isi materi pembelajaran termasuk kriteria baik dengan persentase tingkat pencapaian 92,5\%. Media pembelajaran ini termasuk kriteria sangat baik karena sudah disesuaikan kurikulum 2013 terbaru yang sudah di revisi yaitu tahun 2017.

Ahli desain pembelajaran yang memberikan penilaian serta tanggapan terhadap media ini adalah Dr. I Made Tegeh, S.Pd. M. Pd. Kualitas media ditinjau dari desain pembelajaran termasuk kriteria sangat baik dengan persentase tingkat pencapaian 92,22\%. Media pembelajaran ini dikatakan sangat baik pada pengembangannya menerapkan prinsip-prinsip pengembangan media yaitu dengan menerapkan teori desain pembelajaran yang bertujuan proses pembelajaran lebih terstruktur.

Ahli media pembelajaran yang memberikan penilaian serta tanggapan terhadap media ini adalah Bapak Dr. I Gde Wawan Sudatha, S.Pd., S.T., M.Pd. Berdasarkan hasil penilaian dari ahli media, terungkap bahwa sebagian besar penilaian ahli media terhadap komponen-komponen Multimedia Pembelajaran berbasis inkuiri tersebar pada skor 4 (baik) dan 5 (sangat baik). Kualitas media ditinjau dari media pembelajaran termasuk kriteria baik dengan persentase tingkat pencapaian 84,7\%. Media pembelajaran ini dikatakan baik pada pengembangannya menerapkan teori desain pesan meliputi aspek visual dan audio. 
Pada tahap uji coba perorangan dengan memperoleh rerata persentase 93,3.\%. Setelah dikonversi dengan tabel konversi, persentase tersebut berada pada kualifikasi sangat baik, sehingga Multimedia Pembelajaran berbasis inkuiri tidak perlu direvisi.

Pada tahap uji coba kelompok kecil dengan memperoleh rerata persentase 90,6\%. Setelah dikonversi dengan tabel konversi, persentase tersebut berada pada kualifikasi sangat baik, sehingga Multimedia Pembelajaran berbasis inkuiri tidak perlu direvisi.

Tahap uji coba media selanjutnya adalah uji coba lapangan. Berdasarkan hasil penilaian dari hasil uji coba lapangan, Multimedia pembelajaran berbasis inkuiri memperoleh rerata persentase tingkat pencapaian adalah 87,7\%. maka Multimedia Pembelajaran berbasis inkuiri tidak ada revisi lagi.

Dalam pengembangan multimedia pembelajaran ini melalui enam tahapan yaitu uji ahli isi mata pelajaran, uji ahli desain pembelajaran, uji ahli media pembelajaran, uji coba perorangan, uji coba kelompok kecil, dan uji coba lapangan. Dalam ke enam tahapan tersebut tidak ada yang perlu banyak direvisi namun hanya ada beberapa tambahan dan masukan dari para ahli dan subjek uji coba.

Sebelum menguji efektivitas produk pengembangan multimedia pembelajaran pada pembelajaran IPA, peneliti melakukan pretest terhadap 29 siswa di kelas VIISMP Negeri 2 gerokgak. Selanjutnya diteruskan melakukan posttest terhadap 29 siswa. Adapun hasil pretest dan posttest disajikan dalam tabel berikut.

Tabel 2.Hasil Pretest dan Posttest pada Mata Pelajaran IPA

\begin{tabular}{llll}
\hline No & Banyak Responden & Pretest & Posttest \\
\hline 1 & 29 siswa & 1690 & 2396,67 \\
& Rata-rata & 58,28 & 82,64 \\
\hline
\end{tabular}

Dari hasil analisis pretest dan posttest 29 siswa diperoleh rata-rata pretest sebesar 58,28 dan nilai ratarata posttest sebesar 74,896. Berdasarkan nilai pretest dan posttest 29 siswa tersebut, maka dilakukan uji-t untuk sampel berkorelasi secara manual. Sebelum melakukan uji hipotesis (uji-t), perlu dilakukan uji prasyarat analisis data yang meliputi uji normalitas dan uji homogenitas. Adapun pemaparannya sebagai berikut. (1) Uji Normalitas. Uji normalitas data dilakukan untuk menyajikan bahwa sampel benar-benar berasal dari populasi yang berdistribusi normal. Uji normalitas data dilakukan terhadap data 29 siswa dari hasil belajar IPA siswa sebelum dan sesudah menggunakan multimedia pembelajaran. Uji normalitas data dilakukan dengan teknik Chi Kuadrat. Berdasarkan hasil analisis uji normalitas data yang dilakukan, dapat disajikan pada tabel berikut.

Tabel 3. Hasil Uji Normalitas Pretest dan Posttest

\begin{tabular}{|c|c|c|c|c|c|c|}
\hline No & Kelompok Data Hasil Belajar & $\chi 2$ hitung & $\chi 2$ tabel & \multicolumn{3}{|c|}{ Status } \\
\hline & 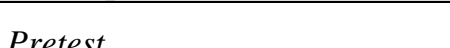 & 5. & & 7,81 & & Norm \\
\hline & Fretest & 2 & 5 & & al & \\
\hline & Postest & 3.2 & 5 & 7.81 & al & Norm \\
\hline
\end{tabular}

Berdasarkan Tabel 3 terlihat bahwa hasil perhitungan dengan menggunakan rumuschi-kuadrat, diperoleh $\chi 2$ hitung $<\chi 2$ tabel dengan tarafsignifikansi 5\%. Dengan demikian semua data skor hasil belajar IPA berdistribusi normal. (2) Uji Homogenitas. Homogenitas data dianalisis dengan uji-F, dengan kriteria data homogen jika F2hitung $\leq$ F2tabel, dan data tidak homogen jika F2hitung $\geq$ F2tabel.Hasil homogenitas disajikan dalam tabel berikut.

Tabel 4. Hasil Uji Homogenitas Pretest dan Posttest

\begin{tabular}{llcc}
\hline Data & Fhitung & Ftabel & \multicolumn{2}{c}{ Keterangan } \\
\hline $\begin{array}{l}\text { Pretest } \\
\text { Postest }\end{array}$ & 1,849 & 2.674 & Homogen \\
\hline
\end{tabular}

Berdasarkan hasil pengujian diperoleh Fhitung $=1,849$ sedangkan Ftabel= 2,674 dengan taraf signifikansi 5\%. Jadi dapat disimpulkan Fhitung $\leq$ Ftabel sehingga kedua data tersebut memiliki varians yang homogen. (3) Uji Hipotesis. Pengujian hipotesis penelitian dilakukan dengan analisis uji-t sampel berkorelasi. Semua pengujian hipotesis dilakukan pada taraf signifikansi 5\%. Kriteria pengujian adalah apabila hasil perhitungan diperoleh nilai thitung > ttabel maka H0 ditolak dan H1 diterima. Hasil uji-t disajikan pada tabel sebagai berikut. 
Tabe 5. Rangkuman Hasil Uji-t

\begin{tabular}{rcccccc}
\hline Data & $\mathrm{N}$ & Rata-rata & $\mathrm{s}^{2}$ (Varians) & Db (n1+n2-2) & Thit & Ttab \\
\hline Pretest & \multirow{2}{*}{27} & 50,56 & 195,73 & 3 & \multirow{2}{*}{14,10} & 2,003 \\
Postest & & 87,778 & 105,85 & 3 & \\
\hline
\end{tabular}

Berdasarkan hasil uji-t diperoleh thitung $=14,10$ dan ttabel $=2,003$ untuk $\mathrm{db}=3$ dari taraf signifikansi 5\%. Hal ini berarti thitung > ttabel, sehingga H0 ditolak dan H1diterima. Berdasarkan kriteria pengujian, H0 ditolak dan H1 diterima yang artinya multimedia pembelajaran IPA tentang Pencemaran Lingkungan efektif dalam meningkatkan hasil belajar siswa kelas IV pada mata pelajaran IPA di SMP Negeri 2 Gerokgak tahun pelajaran 2018/2019.

Pembahasan dalam penelitian pengembangan ini membahas hasil-hasil pengembangan untuk menjawab pertanyaan dalam pengembangan Multimedia Pembelajaran berbasis inkuiri IPA untuk siswa kelas VII semester genap tahun pelajaran 2018/2019 di SMP Negeri 2 Gerokgak. Secara umum ada 3 pertanyaan ilmiah yang harus dijawab dalam penelitian pengembangan Multimedia Pembelajaran berbasis inkuiri IPA ini yaitu. (1) Bagaimanakah rancang bangun Multimedia Pembelajaran berbasis inkuiri mata pelajaran IPA kelas VII Semester Genap Tahun Pelajaran 2018/2019 di SMP Negeri 2 Gerokgak?, (2) Bagaimanakah kualitas hasil pengembangan Multimedia Pembelajaran berbasis inkuiri menurut review ahli, uji perorangan, uji kelompok kecil, dan uji lapangan?, (3) Bagaimanakah efektivitas hasil pengembangan Multimedia Pembelajaran berbasis inkuiri terhadap hasil belajar siswa pada mata pelajaran IPA Kelas VII Semester Genap Tahun Pelajaran 2018/2019 di SMP Negeri 2 Gerokgak?

Produk yang dikembangkan adalah multimedia pembelajaran berbasis inkuiri. Pengembangan Multimedia Pembelajaran berbasis inkuiri ini telah dikembangkan melalui beberapa tahapan sesuai dengan model pengembangan model Luther. Uttami \& Datta (2017) menyebutkan model Luther ini memiliki langkahlangkah pengembangannya sistematis, disajikan secara ringkas, dan dan setiap langkah dipaparkan secara jelas. Tahapan-tahapan dari model Luther yaitu: (1) Konsep (Concept) adalah tahap untuk menentukan tujuan dan siapa pengguna program (identifikasi audiens). Karakteristik pengguna termasuk kemampuan pengguna. Berdasarkan analisis siswa yang telah dilakukan siswa SMP Negeri 2 Gerokgak lebih tertarik belajar menggunakan multimedia pembelajaran daripada menggunakan metode ceramah.

Selain itu, tahap ini juga menentukan jenis aplikasi (presentasi, interaktif, dan lain-lain). Jenis multimedia yang dikembangkan dalam penelitian ini adalah multimedia presentasi. (2) Design (perancangan) adalah tahap pembuatan spesifikasi mengenai arsitektur program, gaya, tampilan, dan kebutuhan material/bahan untuk program. Untuk menggambarkan aliran dari satu scene ke scene lain perlu dibuat bagian alir (flowchart). Selanjutnya, berdasarkan flowchart disusun storyboard untuk menggambarkan deskripsi tiap scene, dengan mencantumkan semua objek multimedia dan tautan ke scene lain. Pembuatan storyboard menggunakan cara pembuatan storyboard film/animasi.

Tahap 3: Pengumpulan bahan (Collecting material) ini berupa pengumpulan bahan atau materi pelajaran yang diperlukan untuk pembuatan produk, seperti materi pokok (substansi mata pelajaran IPA), aspek pendukung seperti gambar, video, audio, dan clip-art image. Pengumpulan materi pokok dilakukan dengan menggunakan buku mata pelajaran IPA yang digunakan di SMP Negeri 2 Gerokgak, sedangkan pengumpulan gambar, video, dan audio diperoleh melalui pembuatan sendiri, arsip pribadi, ataupun men-download melalui internet serta pengambilan langsung di lapangan. (4) Pembuatan (Assembly) merupakan tahap untuk menyusun materi pelajaran IPA yang telah disiapkan dan dimasukkan pada setiap halaman/frame dengan menggunakan software yang sudah ditentukan. Pada tahap ini dilakukan perakitan media/penggabungan seluruh bahan seperi materi pelajaran, gambar, animasi, teks, audio, dengan bantuan software Macromedia Flash 8, Adobe Photoshop CS5, Sony Vegas Pro. Penggabungan ini dimaksudkan agar komponen-komponen multimedia menjadi satu media utuh. (5) Uji coba (Testing) Uji coba media merupakan hal yang terpenting dalam pengembangan media pembelajaran ini.Tahap Testing (pengujian) dilakukan setelah menyelesaikan tahap assembly dengan menjalankan aplikasi/program dan melihatnya apakah ada kesalahan atau tidak. Tahapan uji selanjutnya dalam pengembangan media ini, meliputi uji coba ahli isi mata pelajaran, uji coba ahli desain pembelajaran, uji coba ahli media pembelajaran, uji coba perorangan dengan, uji kelompok kecil, dan uji coba lapangan. (6) Distribusi (Distribution) adalah tahap penyebarluasan produk hasil pengembangan. Pada tahap ini dilakukan kegiatan berupa distribusi produk CD multimedia presentasi kepada guru IPA kelas VII di SMP Negeri 2 Gerokgak.

Berdasarkan hasil yang diperoleh dari uji coba siswa, baik uji coba perorangan, kelompok kecil dan lapangan menunjukan multimedia pembelajaran yang dikembangkan dari segi kemenarikan berada pada kategori sangat baik. Oleh sebab itu, maka tidak heran multimedia pembelajaran yang dikembangkan efektif digunakan dalam proses pembelajaran. Kefektifan multimedia pembelajaran dapat dilihat puladari hasil belajar siswa setelah menggunakan multimedia pembelajaran yang meningkat dengan skor rata-rata siswa, yaitu 82,46 dari sebelum menggunakan multimedia pembelajaran skor rata-rata siswa hanya 58,28. 
Dilihat dari konversi hasil belajar di kelas VII SMP Negeri 2 Gerokgak, nilai rata-rata postest peserta didik 82,64 berada pada kualifikasi baik, dan berada di atas nilai KKM mata pelajaran IPA sebesar 75. Melihat nilai rata-rata atau mean posttest yang lebih besar dari nilai rata-rata atau mean pretest, dapat dikatakan bahwa Multimedia Pembelajaran berbasis inkuiri pada mata pelajaran IPA dapat meningkatkan hasil belajar IPA siswa hal ini sejalan dengan penelitian pengembangan multimedia berbasisi inkuiri yang dilakukan oleh Wijarini (2014) bahwa kolaborasi multimedia pembelajaran interaktif dengan pembelajaran inkuri dapat meningkatkan hasil belajar hal ini sesuai dengan penelitian yang dilakukan (Syahdini: 2015) bahwa Multimedia interaktif berbasis inkuiri juga meningkatkan hasil belajar dan melatihkan keterampilan berpikir kritis siswa. Multimedia interaktif ini potensial untuk menuntun kegiatan praktik sekaligus menggali gagasan awal siswa.Keunggulan multimedia interaktif yang dikembangkan memberikan kasus-kasus yang cukup menantang dan mendorong siswa untuk berpikir kritis dan kreatif. Kasus yang diberikan tidak hanya secara verbal, tetapi didukung dengan visualisasi berupa gambar,video, simulasi dan animasi yang sangat menarik. (Ningrum et al 2016).

\section{Simpulan}

Berdasarkan hasil dan pembahasan pada penelitian ini, maka dapat diambil simpulan sebagi berikut.

(1) Rancang bangun atau tahapan-tahapan pengembangan multimedia presentasi ini telah dikembangkan melalui beberapa tahapan. Tahapan pengembangan multimedia ini menggunakan model Luther sebagi acuan. Tahapan dari model ini yaitu ini yaitu (1) Konsep (Concept), (2) Perancangan (Design), (3) Pengumpulan bahan (Material Collecting), (4) Pembuatan (Assembly), (5) Uji coba (Testing), (6) Distribusi (Distribution). (2)Kualitas multimedia presenatasi berdasarkan review ahli isi mata pelajaran, multimedia presentasi berada pada kualifikasi sangat baik (92,5\%). Menurut ahli desain pembelajaran, multimedia presenatsi berada pada kualifikasi sangat baik $(92,22 \%)$. Menurut ahli media pembelajaran multimedia presentasi berada pada kualifikasi baik $(84,7 \%)$. Pada tahap uji coba perorangan, mutimedia presentasi yang diuji berada pada tingkat pencapaian 93,3\% atau berada pada kualifikasi sangat baik. Pada tahap uji coba kelompok kecil, multimedia presentasi memiliki tingkat pencapaian 90,6\% atau berada pada kualifikasi sangat baik. Dan pada tahap uji coba lapangan diperoleh tingkat pencapaian sebesar $87,7 \%$ atau berada pada kualifikasi baik. Dengan demikian multimedia presentasi yang dikembangkan sangat baik. (3) Efektivitas produk penelitian pengembangan dalam penelitian ini diukur dengan melakukan tahap pretest dan posttest. Rata-rata nilai pretest sebesar 58,28 dan rata-rata nilai posttest sebesar 82,64. Setelah dilakukan penghitungan secara manual diperoleh hasil t hitung sebesar 14,10. Kemudian harga t hitung dibandingkan dengan harga t tabel dengan $\mathrm{db}=\mathrm{n} 1+\mathrm{n} 2-2$ $=29+29-2=56$. Harga $t$ tabel untuk db 56 dan dengan taraf signifikansi $5 \%(\alpha=0.05)$ adalah 2,003 . Harga $t$ hitung yaitu 14,10 lebih besar daripada harga t tabel, sehingga H0 ditolak dan H1 diterima. Hal ini berarti, terdapat perbedaan signifikan terhadap hasil belajar IPA siswa antara sebelum dan sesudah menggunakan multimedia presentasi. Dengan demikian multimedia presentasi efektif untuk meningkatkan hasil belajar IPA siswa kelas VII SMP Negeri 2 Gerokgak.

Berdasarkan simpulan, adapun saran berkaitan dengan pengambangan multimedia pembelajaran presentasi ini adalah sebagai berikut.

(1) Bagi Siswa, penerapan multimedia presentasi dalam pembelajaran IPA akan memberikan contoh lebih nyata bagi siswa dibandingakan dengan metode ceramah, karena dengan penggunaan multimedia presentasi, siswa akan mendapat contoh lebih konkret sehingga pemahaman siswa mengenai materi pelajaran IPA akan semakin bertambah. (2) Bagi Guru, saran bagi guru adalah agar multimedia presentasi ini diterapkan lebih lanjut. Dengan penerapan multimedia ini dalam proses pembelajaran maka tingkat motivasi dan pemahaman siswa akan meningkat. (3) Bagi Kepala Sekolah,saran bagi kepala sekolah adalah agar mengelola dan multimedia pembelajaran ini dengan baik, sehingga koleksi sumber belajar lebih ini dapat dimanfaatkan oleh guru dan siswa. (4) Bagi peneliti Lain, dari penelitian pengembangan yang sudah dilakukan telah terjadi perkembangan yang bagus. Berdasarkan uji coba yang dilakukan di SMP Negeri 2 Gerokgak dapat disimpulkan penerapan multimedia efektif dalam meningkatkan hasil belajar. Maka dari itu diharapkan agar penelitian selanjutnya pengembangan multimedia menggunakan mata pelajaran selain IPA untuk mengetahui tingkat efektivitas multimedia pembelajaran pada mata pelajaran lain.

\section{Daftar Pustaka}

Agung, A.A.Gede. 2014. Metodologi Penelitian Pendidikan. Malang: Aditya Media Publising.. Arsyad, A. 2005.Media Pembelajaran.Jakarta: PT Raja Grafindo Persada. Arsyad, A, 2011.Media Pembelajaran.Jakarta: PT Raja Grafindo Persada Aunurrahman.2009. Belajar dan Pembelajaran.Bandung: Alfabeta Koyan, I W. 2011.Asesmen dalam Pendidikan..Singaraja: Undiksha Press. Koyan, I Wayan.2012. Statistik Pendidikan Teknik Analisis Data Kuantitatif.Singaraja: Undiksha Press. 
Latief, M A. 2009.Pengembangan Penelitian. Pendidikan bahasa inggris Fakultas sastra,Universitas negeri malang:2009

Rohani, Ahmad. 1997. Media Instruksional Edukatif. Jakarta: Rineka Cipta.

Sanjaya, Wina. 2010. Perencanaan dan Desain Sistem Pembelajaran. Jakarta: Kencana.

Sanjaya, Wina. 2006. Strategi Pembelajaran Berorientasi Standar Proses Pendidikan. Jakarta: Kencana.

Santyasa, Wayan. 2009. Metode Penelitian Pengembangan dan Teori Pengembangan Modul.Makalah Disajikan dalam Pelatihan Bagi Para Guru TK, SD, SMP, SMA, dan SMK: Tanggal 12-14 Januari 2009 Di Kecamatan Nusa Penida Kabupaten Klungkung.

Setyosari, P. 2012. Metode Penelitian Pendidikan dan Pengembangan.Jakarta: Kencana Prenada Media Group.

Suartama, I Kadek.dan I Komang. Sudarma. 2007. Laporan Penelitian Pengembangan Compac Disc Multimedia Interaktif pada Mata Kuliah Media Pembelajaran. Singaraja: Undiksha.

Sudarma, I Komang.dan Arya Oka. 2008. Teknik Produksi \& Pengembangan Multimedia pembelajaran. Singaraja: Undiksha.

Sudatha, I.G.W.dan I Made Tegeh.2009. Desain Multimedia Pembelajaran.Singaraja: UniversitasPendidikanGanesha.

Sukardi.2008. Metodologi Penelitian Pendidikan Kompetensi dan Praktiknya. Jakarta: PT Bumi Aksara

Tegeh, I Made \& I Made Kirna. 2010. Metode Penelitian Pengebangan Pendidikan. Singaraja: Universitas Pendidikan Ganesha. 